\title{
IMPLEMENTASI CORPORATE SOCIAL RESPONSIBILITY PT. RIAU ANDALAN PULP AND PAPER TERHADAP MASYARAKAT DI KABUPATEN PELALAWAN
}

\author{
Andrew Shandy Utama \\ Dosen Fakultas Hukum Universitas Lancang Kuning \\ Email: andrew.fh.unilak@gmail.com
}

\begin{abstract}
Corporate Social Responsibility (CSR) is an inherent responsibility of the company to keep creating harmonious, balanced, and harmonious relationships with the environment, values, norms and culture of the community. Corporate Social Responsibility is basically a derivation of business ethics, which can bridge the interests of the company with the needs of the community, both directly and indirectly affected by the company's operations. The problem is how is the regulation of Corporate Social Responsibility in the legal system in Indonesia? How is the implementation of Corporate Social Responsibility of PT Riau Andalan Pulp and Paper on improving people's welfare in Pelalawan Regency? The method used in this research is sociological law research using approach to the implementation of legislation, namely Law Number 40 Year 2007 and Riau Province Regional Regulation No. 6 of 2012, on the implementation of Corporate Social Responsibiity PT Riau Andalan Pulp and Paper. The result of this research is that Corporate Social Responsibility which initially is only the moral responsibility for the company to the society residing in the vicinity of the company's location is now transformed into legal responsibility in the form of obligation for the company to improve the prosperity of the people who live around the company location according to Law Number 40 of 2007 which is implemented in Riau Province with Riau Province Regional Regulation Number 6 of 2012. PT Riau Andalan Pulp and Paper has implemented Corporate Social Responsibility to improve community welfare in Pelalawan Regency in accordance with the provisions regulated by law - the prevailing law.
\end{abstract}

Keywords: Corporate Social Responsibility; The Implementation; Public Welfare

\begin{abstract}
Abstrak
Corporate Social Responsibility (CSR) adalah tanggung jawab yang melekat pada perusahaan untuk tetap menciptakan hubungan yang serasi, seimbang, dan selaras dengan lingkungan, nilai, norma, dan budaya masyarakat. Corporate Social Responsibility pada dasarnya merupakan derivasi dari etika bisnis, yang dapat menjembatani antara kepentingan perusahaan dengan kebutuhan masyarakat, baik yang terkena dampak langsung maupun tidak langsung dari operasional perusahaan tersebut. Permasalahannya adalah bagaimanakah pengaturan mengenai Corporate Social Responsibility dalam sistem hukum di Indonesia? Bagaimanakah implementasi Corporate Social Responsibility PT Riau Andalan Pulp and Paper terhadap peningkatan kesejahteraan masyarakat di Kabupaten Pelalawan? Metode yang digunakan dalam penelitian ini adalah penelitian hukum sosiologis dengan menggunakan pendekatan implementasi peraturan perundang-undangan, yaitu Undang-Undang Nomor 40 Tahun 2007 dan
\end{abstract}


Peraturan Daerah Provinsi Riau Nomor 6 Tahun 2012, terhadap implementasi Corporate Social ResponsibilityPT Riau Andalan Pulp and Paper. Hasil dari penelitian ini adalah bahwa Corporate Social Responsibility yang pada awalnya hanya merupakan tanggung jawab moral bagi perusahaan terhadap masyarakat yang bertempat tinggal di sekitar lokasi perusahaan saat ini berubah menjadi tanggung jawab hukum berupa kewajiban bagi perusahaan untuk meningkatkan kesejahteraan masyarakat yang bertempat tinggal di sekitar lokasi perusahaan tersebut menurut Undang-Undang Nomor 40 Tahun 2007 yang diimplementasikan di Provinsi Riau dengan Peraturan Daerah Provinsi Riau Nomor 6 Tahun 2012. PT Riau Andalan Pulp and Paper telah melaksanakan Corporate Social Responsibility untuk meningkatkan kesejahteraan masyarakat di Kabupaten Pelalawan sesuai dengan ketentuan yang diatur oleh peraturan perundang-undangan yang berlaku.

Kata kunci: Corporate Social Responsibility; Implementasi; Kesejahteraan Masyarakat

\section{Pendahuluan}

Menurut Undang-Undang Nomor 40 Tahun 2007, Perseroan Terbatas (perusahaan) adalah badan hukum yang merupakan persekutuan modal, didirikan berdasarkan perjanjian, melakukan kegiatan usaha dengan modal dasar yang seluruhnya terbagi dalam saham, dan memenuhi persyaratan yang ditetapkan oleh undang-undang dan peraturan pelaksanaannya. ${ }^{1}$

Keberadaan perusahaan telah menjadi institusi bisnis yang dominan. Perusahaan telah memberikan pengaruh bagi pembangunan ekonomi nasional. Aktivitas perusahaan secara nyata telah memberikan lapangan kerja, memberikan produk barang maupun jasa yang diperlukan untuk kehidupan masyarakat, meningkatkan pembangunan ekonomi berkelanjutan, meningkatkan kapasitas dan kemampuan teknologi nasional, serta mewujudkan kesejahteraan masyarakat dalam suatu sistem perekonomian yang berdaya saing.

Berbagai peraturan telah dibuat terkait dengan kelembagaan dan aktivitas bisnis perusahaan. Secara prinsip, perusahaan adalah lembaga privat yang didirikan dengan modal dengan tujuan utamanya mencari keuntungan. Hal ini yang seringkali menjadi alasan perusahaan untuk melakukan aktivitas bisnis tanpa memperhatikan nilai moral dan etika bisnis, sehingga operasional perusahaan menimbulkan berbagai persoalan sosial seperti ketimpangan sosial, menimbulkan dampak lingkungan yang tidak nyaman, pemborosan penggunaan sumber daya alam, ketidaksetaraan kedudukan antara produsen dan konsumen, serta ketidaksamaan posisi tawar antara perusahaan dan karyawan. Bahkan, tanpa disadari, perusahaan telah melakukan pencelaan terhadap harkat dan martabat kemanusiaan dan lingkungan hidup secara luas.

Dari sisi yang lain, interaksi antara perusahaan dengan masyarakat secara sosial semakin lekat. Perusahaan telah masuk dan mempengaruhi semua lini kehidupan masyarakat. Perusahaan, selain sebagai institusi bisnis, juga telah menjadi bagian dari warga negarayang terlibat langsung dengan dinamika masyarakat. Keberlanjutan bisnis perusahaan juga sangat bergantung pada kondisi ekonomi dan kualitas kehidupan masyarakat. Perusahaan tidak boleh hanya mencari keuntungan semata, tetapi juga harus

1 Pasal 1 Angka 1 Undang-Undang Nomor 40 Tahun 2007 tentang Perseroan Terbatas 
ikut serta memperhatikan kelestarian lingkungan hidup dan peduli pada persoalan sosial yang dihadapi masyarakat.

Secara umum, prinsip-prinsip yang berlaku dalam kegiatan bisnis yang baik sesungguhnya tidak bisa dilepaskan dari kehidupan kita sebagai manusia pada umumnya. Prinsip-prinsip itu sangat erat terkait dengan sistem nilai yang dianut oleh masyarakat. Prinsip-prinsip dalam etika bisnis antara lain yaitu prinsip otonomi, prinsip kejujuran, prinsip berbuat baikdan tidak berbuat jahat, prinsip keadilan, serta prinsip hormat kepada diri sendiri. ${ }^{2}$

Tanggung jawab sosial pada dasarnya merupakan derivasi dari etika bisnis. Etika bisnis ini timbul dari adanya interaksi bisnis antara manusia yang saling melengkapi pemenuhan kebutuhan antara yang satu dengan yang lain sebagai akibat dari kompleksitas kebutuhan manusia yang kian berkembang dan tidak terbatas. Etika bisnis dapat menjembatani kepentingan antara kebutuhan perseroan dengan masyarakat sosial, baik yang terkena dampak langsung maupun tidak langsung dari operasional perseroan tersebut. ${ }^{3}$

Dilihat dari sudut pandang hukum bisnis, setidaknya ada dua tanggung jawab yang harus diajarkan dalam etika bisnis, yaitu tanggung jawab hukumdan tanggung jawab sosial. Tanggung jawab hukum meliputi aspek perdatadan aspek pidana, sedangkan tanggung jawab sosial dibangun di atas landasan norma moral yang berlaku di masyarakat. ${ }^{4}$

Penerapantanggung jawab sosial perusahaan (Corporate Social Responsibility/CSR) oleh perusahaan berarti bahwa perusahaan bukan hanya merupakan entitas bisnis yang hanya berusaha mencari keuntungan semata, tetapi perusahaan merupakan satu kesatuan dengan keadaan ekonomi, sosial, dan lingkungan tempatnya beroperasi. $^{5}$

Berdasarkan uraian di atas, maka rumusan masalah yang akan dibahas dalam penelitian ini adalah sebagai berikut:

1. Bagaimanakah pengaturan mengenai Corporate Social Responsibility dalam sistem hukum di Indonesia?

2. Bagaimanakah implementasi Corporate Social Responsibility PT Riau Andalan Pulp and Paper terhadap peningkatan kesejahteraan masyarakat di Kabupaten Pelalawan?

\section{Tinjauan Pustaka}

Berbagai literatur yang membahas mengenai Corporate Social Responsibility (CSR) telah banyak ditulis oleh para ahli. Salah satunya yaitu yang terdapat dalam buku "Status Badan Hukum, Prinsip-prinsip, dan Tanggung Jawab Sosial Perseroan Terbatas" karangan Habib Adjie. Dalam bukunya tersebut, Habib Adjie membahas Corporate Social Responsibility mulai dari arti tanggung jawab sosial perusahaan, ruang lingkup tanggung jawab sosial perusahaan, serta hubungan tanggung jawab sosial perusahaan dengan etika bisnis. ${ }^{6}$ Akan tetapi, di dalam buku tersebut tidak ada membahas mengenai implementasi Corporate Social Responsibility perusahaan terhadap peningkatan kesejahteraan masyarakat.

2 Ridwan Khairandy.Perseroan Terbatas; Doktrin, Peraturan Perundang-undangan, dan Yurisprudensi. Yogyakarta: Kreasi Total Media, 2009, hlm. 132-134.

3 Fahmi.Pergeseran Tanggung Jawab Sosial Perseroan; Dari Tanggung Jawab Moral ke Tanggung Jawab Hukum. Yogyakarta: FH Ull Press, 2015, hlm. 37.

Ridwan Khairandy.Perseroan..... Op. Cit., hlm. 138.

5 Ibid.

6 Habib Adjie.Status Badan Hukum, Prinsip-prinsip, dan Tanggung Jawab Sosial Perseroan Terbatas. Bandung: Mandar Maju, 2008, hlm. 61-71. 
Pada Jurnal Respublica, Zulfikar Jayakusuma menulis dengan judul "Tanggung Jawab Sosial Perusahaan Transnasional Pertambangan Minyak terhadap Masyarakat Lokal (Perspektif Hak Asasi Manusia)". Menurutnya, mengintegrasikan tanggung jawab sosial perusahaan dengan hak asasi manusia merupakan parameter untuk mengukur pelaksanaan tanggung jawab sosial perusahaan terhadap masyarakat lokal. ${ }^{7}$

Selain itu, pada Jurnal IImu Hukum, Firdaus menulis dengan judul "Corporate Social Responsibility; Transformasi Moral ke dalam Hukum dalam Membangun Kesejahteraan Masyarakat". Menurutnya, Undang-Undang Nomor 25 Tahun 2007 dan Undang-Undang Nomor 40 Tahun 2007 telah merubah paradigma tanggung jawab sosial perusahaan dari bersifat sukarela yang berdasarkan moral menjadi kewajiban hukum. ${ }^{8}$ Pada Jurnal Respublica, Firdaus juga menulis dengan judul "Corporate Social Responsibility dalam Hak Asasi Manusia; Studi terhadap Pemenuhan Hak Ekonomi Sosial Masyarakat Lokal oleh Perusahaan Perkebunan Kelapa Sawit". Menurutnya, Corporate Social Responsibility merupakan konstruksi hukum negara untuk memberi jaminan agar pengelolaan sumber daya alam oleh perusahaan perkebunan kelapa sawit memberi kemakmuran bagi masyarakat. ${ }^{9}$

Sejalan dengan itu, pada Jurnal Masalahmasalah Hukum, Nur Sulistyo B. Ambarini menulis dengan judul "Audit Lingkungan sebagai Perwujudan Tanggung Jawab Sosial Perusahaan di Era Globalisasi Ekonomi". Menurutnya, audit lingkungan yang dilaksanakan oleh perusahaan secara periodik merupakan perwujudan dari Corporate Social Responsibility. Selain itu, perusahaan dapat membina hubungan yang baik dengan masyarakat di sekitarnya dengan melakukan aktivitas yang bersifat pemberdayaan masyarakat. ${ }^{10}$

Selanjutnya, pada Jurnal Mimbar Hukum, Budi Santoso menulis dengan judul "Pendekatan Hukum terhadap Pembangunan Berkelanjutan Melalui Pengaturan Tanggung Jawab Sosial Perusahaan". Menurutnya, tanggung jawab sosial perusahaan dianggap sebagai sebuah jawaban bagi keberhasilan pembangunan internasional yang berkelanjutan. ${ }^{11}$

Kemudian, padaJurnal Ahkam, Yayan Sopyan menulis dengan judul "Corporate Social Responsibility (CSR) sebagai Implementasi Fikih Sosial untuk Pemberdayaan Masyarakat". Menurutnya, pemerintah harus mendorong perusahaan dalam melaksanakan Corporate Social Responsibility dari bersifat sukarela menjadi bersifat mengikat, sehingga eksistensi Corporate Social Responsibility dapat dirasakan lebih nyata oleh masyarakat. ${ }^{12}$

Pada Jurnal Hukum Novelty, Andrew Shandy Utama dan Rizana menulis dengan judul "Implementasi Corporate Social Responsibility PT

7 Zulfikar, Jaya Kusuma. "Tanggung Jawab Sosial Perusahaan Transnasional Pertambangan Minyak terhadap Masyarakat Lokal (Perspektif Hak Asasi Manusia)". Respublica, 2007: Volume 7, Nomor 1, halaman. 111.

8 Firdaus. "Corporate Social Responsibility; Transformasi Moral ke dalam Hukum dalam Membangun Kesejahteraan Masyarakat". IImu Hukum, Agustus 2010: Edisi I, Nomor 1, halaman. 16.

$9 \quad$ Firdaus."Corporate Social Responsibility dalam Hak Asasi Manusia; Studi terhadap Pemenuhan Hak Ekonomi Sosial Masyarakat Lokal oleh Perusahaan Perkebunan Kelapa Sawit”. Respublica, 2011: Volume 11, Nomor 1, halaman. 2-3.

10 Nur,Sulistyo B. Ambarini“Audit Lingkungan sebagai Perwujudan Tanggung Jawab Sosial Perusahaan di Era Globalisasi Ekonomi".Masalah-masalah Hukum, Maret 2011: Jilid 40, Nomor 1, halaman. 100.

11 Budi, Santoso. "Pendekatan Hukum terhadap Pembangunan Berkelanjutan Melalui Pengaturan Tanggung Jawab Sosial Perusahaan".Mimbar Hukum, November 2011: Edisi Khusus, halaman. 177.

12 Yayan, Sopyan. "Corporate Social Responsibility (CSR) sebagai Implementasi Fikih Sosial untuk Pemberdayaan Masyarakat".Ahkam, Januari 2014: Volume XIV, Nomor 1, halaman. 53. 
Riau Crumb Rubber Factory terhadap Masyarakat Kelurahan Sri Meranti Kota Pekanbaru". Menurutnya, PT Riau Crumb Rubber Factory telah melaksanakan Corporate Social Responsibility, namun belum memenuhi harapan masyarakat Kelurahan Sri Meranti karena tidak sebanding dengan polusi dan kerusakan lingkungan yang diakibatkan oleh kegiatan operasional perusahaan. Hambatannya dari sisi internal perusahaan adalah terbatasnya anggaran dana Corporate Social Responsibility yang dimiliki oleh PT Riau Crumb Rubber Factory untuk dapat memenuhi semua kebutuhan masyarakat, sedangkan dari sisi masyarakat adalah minimnya pengetahuan hukum masyarakat Kelurahan Sri Meranti mengenai Corporate Social Responsibility. ${ }^{13}$

Terakhir, pada Utrecht Journal of International and European Law, dengan judul "Legal Aspects of Corporate Social Responsibility", Tineke Lambooy menulis sebagai berikut:

Corporate Social Responsibility has become a well known concept over the last decade and a half. Employees, government representatives, academic scholars, NGOs and international organizations have been contemplating which role they have to play in regard of Corporate Social Responsibility. Laws have been drafted that promote socially responsible behaviour by companies. International organizations have promoted principles. Companies have adopted Corporate Social Responsibility mission statements and programmes, and are sharing their efforts through sustainability reports. NGOs have contacted companies and pointed out how they can operate in a more responsible way, and academics have analysed all. Corporate Social Responsibility is a subject that has links with many areas of law. ${ }^{14}$
Apabila mencermati berbagai ulasan dalam tinjauan kepustakaan di atas, maka tidak ditemukan pembahasan mengenai implementasi Corporate Social Responsibility PT Riau Andalan Pulp and Paper terhadap peningkatan kesejahteraan masyarakat di Kabupaten Pelalawan. Kalaupun ada pembahasan mengenai implementasi Corporate Social Responsibility, penelitian tersebut dilaksanakan di lokasi yang berbeda dengan penelitian ini.

\section{Metode Penelitian}

Metode yang digunakan dalam penelitian ini adalah penelitian hukum sosiologis dengan menggunakan pendekatan implementasi peraturan perundang-undangan terhadap PT Riau Andalan Pulp and Paper sebagai salah satu perusahaan kehutanan terbesar di Provinsi Riau. Sumber data yang digunakan dalam penelitian ini adalah data primer dan data sekunder. Data primer adalah data yang diperoleh langsung berdasarkan hasil observasi dan wawancara di lokasi penelitian, sedangkan data sekunder adalah data yang diperoleh dari jurnaljurnal ilmiah, literatur hukum, dan peraturan perundang-undangan. Teknik pengumpulan data yang digunakan dalam penelitian ini adalah studi kepustakaan. Teknik analisis data yang digunakan dalam penelitian ini adalah analisis kualitatif.

\section{Hasil Penelitian dan Pembahasan}

\subsection{Pengaturan Mengenai Corporate Social Responsibility (CSR) dalam Sistem Hukum di Indonesia}

13 Andrew, Shandy Utama dan Rizana. IImplementasi Corporate Social Responsibility PT Riau Crumb Rubber Factory terhadap Masyarakat Kelurahan Sri Meranti Kota Pekanbaru".Novelty, Agustus 2017: Volume 8, Nomor 2, halaman. 185.

14 Tineke, Lambooy. "Legal Aspects of Corporate Social Responsibility". Utrecht Journal of International and European Law, 2014: 30 (78), halaman. 1. 
The World Business Council for Suistainable Development menjelaskan bahwa Corporate Social Responsibility dikonsepkan sebagai komitmen dari dunia usaha untuk terus-menerus bertindak secara etis, beroperasi secara legal, dan berkontribusi untuk peningkatan ekonomi bersamaan dengan peningkatan kualitas hidup dari karyawan dan keluarganya, sekaligus peningkatan kualitas komunitas lokal dan masyarakat secara luas. Sedangkan, menurut Salim H.S., konsep Corporate Social Responsibility bukan hanya sebuah komitmen, melainkan sebuah kewajiban. Corporate Social Responsibility adalah kewajiban kemasyarakatan yang harus ditanggung atau dilakukan oleh perusahaan untuk meningkatkan kualitas dan kuantitas masyarakat yang berada di sekitar lingkungan perusahaan maupun di luar lingkungan perusahaan. ${ }^{15}$

Tanggung jawab sosial pada dasarnya merupakan derivasi dari etika bisnis. Etika bisnis ini timbul dari adanya interaksi bisnis antara manusia yang saling melengkapi pemenuhan kebutuhan antara yang satu dengan yang lain sebagai akibat dari kompleksitas kebutuhan manusia yang kian berkembang dan tidak terbatas. Etika bisnis dapat menjembatani kepentingan antara kebutuhan perseroan dengan masyarakat sosial, baik yang terkena dampak langsung maupun tidak langsung dari operasional perseroan tersebut. Dilihat dari sudut pandang hukum bisnis, setidaknya ada dua tanggung jawab yang harus diajarkan dalam etika bisnis, yaitu tanggung jawab hukum dan tanggung jawab sosial. Tanggung jawab hukum meliputi aspek perdata dan aspek pidana, sedangkan tanggung jawab sosial dibangun di atas landasan norma moral yang berlaku di masyarakat.

Pada tahun 2007, terjadi perubahan yang signifikan mengenai Corporate Social Responsibility di Indonesia setelah disahkannya Undang-Undang Nomor 25 Tahun 2007 tentang Penanaman Modal. Lahirnya undang-undang ini bertujuan agar hak, kewajiban, dan tanggung jawab penanam modal diatur secara khusus guna memberikan kepastian hukum, mempertegas kewajiban penanam modal terhadap penerapan prinsip tata kelola perusahaan yang sehat, memberikan penghormatan atas tradisi budaya masyarakat, dan melaksanakan tanggung jawab sosial perusahaan. Ketentuan mengenai Corporate Social Responsibility diatur secara tegas dalam Pasal 15 Huruf b yang menegaskan bahwa setiap penanam modal berkewajiban melaksanakan tanggung jawab sosial perusahaan. ${ }^{16}$

Menurut Undang-Undang Nomor 25 Tahun 2007, tanggung jawab sosial perusahaan adalah tanggung jawab yang melekat pada setiap perusahaan penanaman modal untuk tetap menciptakan hubungan yang serasi, seimbang, dan sesuai dengan lingkungan, nilai, norma, dan budaya masyarakat setempat.

Sejalan dengan itu, disahkannya UndangUndang Nomor 40 Tahun 2007 tentang Perseoran Terbatas semakin menguatkan dasar hukum Corporate Social Responsibility di Indonesia. Undang-undang ini mengatur mengenai tanggung jawab sosial dan lingkungan yang bertujuan mewujudkan pembangunan ekonomi berkelanjutan guna meningkatkan kualitas kehidupan dan lingkungan yang bermanfaat bagi perusahaan itu

\footnotetext{
15 Salim H.S. dan Erlies Septiana Nurbani.Penerapan Teori Hukum pada Penelitian Disertasi dan Tesis. Jakarta: Rajawali Pers, 2016, hlm. 107-108.

16 Pasal 15 Huruf b Undang-Undang Nomor 25 Tahun 2007 tentang Penanaman Modal
} 
sendiri, komunitas setempat, dan masyarakat pada umumnya. Ketentuan mengenai Corporate Social Responsibility diatur secara tegas dalam Pasal 74 Ayat (1) yang menegaskan bahwa perseroan yang menjalankan kegiatan usahanya di bidang dan/atau berkaitan dengan sumber daya alam wajib melaksanakan tanggung jawab sosial dan lingkungan. ${ }^{17}$

Tanggung jawab sosial dan lingkungan merupakan kewajiban perusahaan yang dianggarkan dan diperhitungkan sebagai biaya perusahaan yang pelaksanaannya dilakukan dengan memperhatikan kepatutan dan kewajaran.

Menurut Undang-Undang Nomor 40 Tahun 2007, tanggung jawab sosial dan lingkungan adalah komitmen perseroan untuk berperan serta dalam pembangunan ekonomi berkelanjutan guna meningkatkan kualitas kehidupan dan lingkungan yang bermanfaat, baik bagi perseroan sendiri, komunitas setempat, maupun masyarakat pada umumnya.

Untuk melaksanakan ketentuan Pasal 74 Undang-Undang Nomor 40 Tahun 2007 di atas, maka pemerintah mengeluarkan Peraturan Pemerintah Nomor 47 Tahun 2012 tentang Tanggung Jawab Sosial dan Lingkungan Perseroan Terbatas sebagai aturan teknis bagi perusahaan dalam melaksanakannya.

Selain itu, lahirnya Peraturan Daerah Provinsi Riau Nomor 6 Tahun 2012 tentang Tanggung Jawab Sosial Perusahaan di Provinsi Riau semakin memperkokoh landasan hukum pelaksanaan Corporate Social Responsibility bagi perusahaan-perusahaan yang beroperasi di wilayah
Provinsi Riau, termasuk perusahaan kehutanan seperti PT Riau Andalan Pulp and Paper.

\subsection{Implementasi Corporate Social Responsibility (CSR) PT Riau Andalan Pulp and Paper terhadap Peningkatan Kesejahteraan Masyarakat di Kabupaten Pelalawan}

Di Indonesia, keberadaan Corporate Social Responsibility sudah memperoleh legitimasi untuk dilaksanakan oleh perusahaan. Hal ini tidak terlepas dari dampak negatif yang ditimbulkan dari beroperasinya suatu kegiatan bisnis yang dijalankannya. Kewajiban untuk melaksanakan Corporate Social Responsibility telah diatur di dalam berbagai peraturan perundang-undangan, baik yang terkait dengan perusahaan (Undang-Undang Nomor 40 Tahun 2007 tentang Perseroan Terbatas, UndangUndang Nomor 25 Tahun 2007 tentang Penanaman Modal, dan Undang-Undang Nomor 19 Tahun 2003 tentang Badan Usaha Milik Negara) maupun yang berhubungan dengan Hak Asasi Manusia (UndangUndang Nomor 39 Tahun 1999 tentang Hak Asasi Manusia) dan pembangunan berkelanjutan yang terdapat dalam berbagai undang-undang yang terkait dengan lingkungan. Meskipun masih menimbulkan pro dan kontra, namun dengan adanya peraturan perundang-undangan di atas, maka bagi perusahaan dengan kriteria tertentu menjadi wajib secara hukum (bukan lagi kewajiban moral) untuk melaksanakan Corporate Social Responsibility.18

Penelitian ini dilaksanakan pada PT Riau Andalan Pulp and Paper sebagai salah satu perusahaan kehutanan terbesar di Provinsi Riau, yang berkedudukan di Kabupaten Pelalawan.

\footnotetext{
17 Pasal 74 Ayat (1) Undang-Undang Nomor 40 Tahun 2007 tentang Perseroan Terbatas

18 Sunaryo. "Corporate Social Responsibility (CSR) dalam Perspektif Pembangunan Berkelanjutan". Masalah-masalah Hukum, Januari 2017: Jilid 44, Nomor 1, halaman. 31.
} 
Berdasarkan hasil wawancara dengan Manajer Humas PT Riau Andalan Pulp and Paper, Samsuriya M. Hasyim, diketahui bahwa PT Riau Andalan Pulp and Paper setiap tahunnya rutin melaksanakan Corporate Social Responsibility kepada masyarakat yang bertempat tinggal di sekitar lokasi perusahaan dengan alokasi anggaran yang cenderung meningkat.

Adapun program Corporate Social Responsibility yang dilaksanakan oleh PT Riau Andalan Pulp and Paper adalah sebagai berikut:

1. Integrated farming system, yaitu pemberian bantuan bibit kepada masyarakat yang berwirausaha di bidang pertanian, perkebunan, dan perikanan.

2. UMKM, yaitu pemberian bantuan dana kepada masyarakat yang berwirausaha inline dengan kegiatan perusahaan seperti menjual pupuk tanaman maupun offline dengan kegiatan perusahaan seperti menjual makanan khas daerahnya.

3. Social Infrastructure, yaitupembangunan dan renovasi infrastruktur publik seperti jalan, jembatan, dan rumah ibadah.

4. Education, yaitu pemberian beasiswa pendidikan kepada pelajar berprestasi melalui Yayasan Pendidikan Tanoto Foundation.

5. Vocational training, yaitu pemberian pelatihan teknis kepada generasi muda sebagai bekal dalam memasuki dunia kerja seperti pelatihan las, otomotif, dan menjahit.

6. Employe volunteerism, yaitu kesukarelaan karyawan dalam membantu masyarakat.
Selain melaksanakan Corporate Social Responsibility sesuai dengan program-program yang telah dijelaskan di atas, PT Riau Andalan Pulp and Paper juga memiliki program bernama 'donation', yaitu program Corporate Social Responsibility berupa pemberian bantuan dana kepada organisasi maupun kelompok masyarakat yang mengajukan proposal permohonan bantuan dana melalui Kantor Humas PT Riau Andalan Pulp and Paper. Akan tetapi, anggaran yang disediakan untuk program ini jumlahnya terbatas.

Berdasarkan Peraturan Daerah Provinsi Riau Nomor 6 Tahun 2012, Pemerintah Provinsi Riau membuat Program TJSP (Tanggung Jawab Sosial Perusahaan). Pada Pasal 9 Ayat (1) ditegaskan bahwa setiap perusahaan di Provinsi Riau wajib sebagai pelaksana Program TJSP. ${ }^{19}$ Artinya, ketentuan ini merupakan pelengkap dari ketentuan sebelumnya yang hanya mewajibkan kepada perusahaan yang menjalankan kegiatan usahanya di bidang dan/atau berkaitan dengan sumber daya alam untuk melaksanakan Corporate Social Responsibility. Sebagai bagian dari Program TJSP, Pemerintah Provinsi Riau membentuk Forum TJSP yang dipimpin langsung oleh Gubernur Riau. Forum TJSP bertugas mengawasi pelaksanaan Corporate Social Responsibility perusahaan-perusahaan yang ada di Provinsi Riau, termasuk PT Riau Andalan Pulp and Paper. Pada Pasal 28 Ayat (1) Peraturan Daerah Provinsi Riau Nomor 6 Tahun 2012 ditegaskan bahwa setiap peruhasaan harus memberikan laporan pelaksanaan tanggung jawab sosial perusahaan sekurang-kurangnya sekali dalam setahun kepada pemerintah daerah melalui Forum TJSP. ${ }^{20}$

19 Pasal 9 Ayat (1) Peraturan Daerah Provinsi Riau Nomor 6 Tahun 2012 tentang Tanggung Jawab Sosial Perusahaan di Provinsi Riau

20 Pasal 28 Ayat (1) Peraturan Daerah Provinsi Riau Nomor 6 Tahun 2012 tentang Tanggung Jawab Sosial Perusahaan di Provinsi Riau 
Inilah salah satu bentuk pengawasan Pemerintah Provinsi Riau terhadap pelaksanaan Corporate Social Responsibility oleh perusahaanperusahaan yang beroperasi di Provinsi Riau.

Pelaksanaan Corporate Social Responsibility mampu mempererat hubungan antara perusahaan dan masyarakat karena program Corporate Social Responsibility merupakan upaya yang nyata dari perusahaan dalam meningkatkan kesejahteraan masyarakat. Pelaksanaan Corporate Social Responsibility memberi pengaruh terhadap masyarakat dalam hal peningkatan kualitas kesejahteraannya, baik di bidang sosial, ekonomi, pendidikan, dan lingkungan, seperti akses transportasi dan lowongan pekerjaan. Oleh karena itu, dalam rangka percepatan pembangunan daerah, sebaiknya diwujudkan komitmen bersama antara program-program pemerintah dengan program Corporate Social Responsibility dari perusahaan, untuk meningkatkan kesejahteraan masyarakat. ${ }^{21}$

Apabila ada perusahaan di Provinsi Riau yang tidak melaksanakan Corporate Social Responsibility kepada masyarakat yang bertempat tinggal di sekitar lokasi perusahaan, maka berdasarkan Pasal 32 Peraturan Daerah Provinsi Riau Nomor 6 Tahun 2012, perusahaan tersebut akan dikenakan sanksi administratif oleh Pemerintah Provinsi Riau berupa teguran tertulis dan bentukbentuk sanksi lainnya sesuai dengan peraturan perundang-undangan. ${ }^{22}$

Sejalan dengan itu, Undang-Undang Nomor 25 Tahun 2007 tentang Penanaman Modal dan Undang-Undang Nomor 40 Tahun 2007 tentang
Perseroan Terbatas telah mengatur mengenai sanksi bagi perusahaan yang tidak melaksanakan Corporate Social Responsibility. Pada Pasal 34 UndangUndang Nomor 25 Tahun 2007 disebutkan bahwa perusahaan yang tidak memenuhi kewajibannya melaksanakan tanggung jawab sosial perusahaan dapat dikenai sanksi administratif oleh instansi atau lembaga yang berwenang berupa peringatan tertulis, pembatasan kegiatan usaha, pembekuan kegiatan usaha dan/atau fasilitas penanaman modal, serta pencabutan kegiatan usaha dan/atau fasilitas penanaman modal; ${ }^{23}$ sedangkan Pasal 74 Ayat (3) Undang-Undang Nomor 40 Tahun 2007 menyebutkan bahwa perusahaan yang tidak melaksanakan tanggung jawab sosial dan lingkungan dikenai sanksi sesuai dengan ketentuan peraturan perundang-undangan. ${ }^{24}$

Kebijakan hukum mengenai Corporate Social Responsibility di Indonesia yang bersifat mandatory dengan disertai sanksi sebenarnya sudah tepat. Perubahan paradigm hukum mengenai Hak Asasi Manusia (HAM) yang menjadikan perusahaan sebagai pengemban kewajiban hak ekosob merupakan faktor pendukung yang kuat terhadap model kebijakan hukum mengenai Corporate Social Responsibility di Indonesia. ${ }^{25}$

\section{Kesimpulan}

1. Pengaturan mengenai Corporate Social Responsibility dalam sistem hukum di Indonesia diatur dalam Undang-Undang Nomor 25 Tahun 2007 tentang Penanaman Modal dan Undang-Undang Nomor 40 Tahun

21 Siska, Sukmawaty. "Membangun Daerah Melalui Kebijakan Tanggung Jawab Sosial Perusahaan". Jurnal Selat, Mei 2017: Volume 4, Nomor 2, halaman. 216

22 Pasal 32 Peraturan Daerah Provinsi Riau Nomor 6 Tahun 2012 tentang Tanggung Jawab Sosial Perusahaan di Provinsi Riau

23 Pasal 34 Undang-Undang Nomor 25 Tahun 2007 tentang Penanaman Modal

24 Pasal 74 Ayat (3) Undang-Undang Nomor 40 Tahun 2007 tentang Perseroan Terbatas

25 Sefriani dan Sri Wartini. "Model Kebijakan Hukum Tanggung Jawab Sosial Perusahaan di Indonesia". Ius Quia lustum, Januari 2017: Volume 24, Nomor 2, halaman. 25-26 
2007 tentang Perseroan Terbatas.

Pemerintah mengeluarkan Peraturan

Pemerintah Nomor 47 Tahun 2012 tentang

Tanggung Jawab Sosial dan Lingkungan

Perseroan Terbatas sebagai peraturan

pelaksanaannya. Selain itu, juga ada

Peraturan Daerah Provinsi Riau Nomor 6

Tahun 2012 tentang Tanggung Jawab Sosial

Perusahaan di Provinsi Riau sebagai peraturan pelaksanaannya di Provinsi Riau.

2. Implementasi Corporate Social Responsibility PT Riau Andalan Pulp and Paper terhadap peningkatan kesejahteraan masyarakat di Kabupaten Pelalawan telah dilaksanakan sesuai dengan ketentuan yang diatur oleh peraturan perundang-undangan yang berlaku, yaitu integrated farming system, adalah pemberian bantuan bibit kepada masyarakat yang berwirausaha di bidang pertanian, perkebunan, dan perikanan; UMKM, adalah pemberian bantuan dana kepada masyarakat yang berwirausaha inline dengan kegiatan perusahaan seperti menjual pupuk tanaman maupun offline dengan kegiatan perusahaan seperti menjual makanan khas daerahnya;social infrastructure, adalah pembangunan dan renovasi infrastruktur publik seperti jalan, jembatan, dan rumah ibadah;education, adalah pemberian beasiswa pendidikan kepada pelajar berprestasi melalui Yayasan Pendidikan Tanoto Foundation; vocational training, adalah pemberian pelatihan teknis kepada generasi muda sebagai bekal dalam memasuki dunia kerja seperti pelatihan las, otomotif, dan menjahit;serta employe volunteerism, adalah kesukarelaan karyawan dalam membantu masyarakat.

\section{DAFTAR PUSTAKA}

\section{Buku \& Jurnal}

Adjie, Habib. Status Badan Hukum, Prinsip-prinsip, dan Tanggung Jawab Sosial Perseroan Terbatas. Bandung: Mandar Maju, 2008.

Ambarini, Nur Sulistyo B. "Audit Lingkungan sebagai Perwujudan Tanggung Jawab Sosial Perusahaan di Era Globalisasi Ekonomi". Masalah-masalah Hukum, Maret 2011: Jilid 40, Nomor 1, halaman. 93-101.

Fahmi. Pergeseran Tanggung Jawab Sosial Perseroan; Dari Tanggung Jawab Moral ke Tanggung Jawab Hukum. Yogyakarta: FH UII Press, 2015.
Firdaus. "Corporate Social Responsibility; Transformasi Moral ke dalam Hukum dalam Membangun Kesejahteraan Masyarakat". Ilmu Hukum, Agustus 2010: Edisi I, Nomor 1, halaman. 16-30.

Firdaus. "Corporate Social Responsibility dalam Hak Asasi Manusia; Studi terhadap Pemenuhan Hak Ekonomi Sosial Masyarakat Lokal oleh Perusahaan Perkebunan Kelapa Sawit". Respublica, 2011: Volume 11, Nomor 1, halaman. 1-15

H.S., Salim dan Erlies Septiana Nurbani. Penerapan Teori Hukum pada Penelitian Disertasi dan Tesis. Jakarta: Rajawali Pers, 2016. 
Jayakusuma, Zulfikar. "Tanggung Jawab Sosial Perusahaan Transnasional Pertambangan Minyak terhadap Masyarakat Lokal (Perspektif Hak Asasi Manusia)". Respublica, 2007: Volume 7, Nomor 1, halaman. 101-115.

Khairandy, Ridwan. Perseroan Terbatas; Doktrin, Peraturan Perundang-undangan, dan Yurisprudensi. Yogyakarta: Kreasi Total Media, 2009.

Lambooy, Tineke. "Legal Aspects of Corporate Social Responsibility". Utrecht Journal of International and European Law, 2014: 30 (78), halaman. 1-6.

Santoso, Budi. "Pendekatan Hukum terhadap Pembangunan Berkelanjutan Melalui Pengaturan Tanggung Jawab Sosial Perusahaan". Mimbar Hukum, November 2011: Edisi Khusus, halaman. 164-179.

Sefriani dan Sri Wartini. "Model Kebijakan Hukum Tanggung Jawab Sosial Perusahaan di Indonesia". Ius Quia lustum, Januari 2017: Volume 24, Nomor 1, halaman. 1-28.

Sopyan, Yayan. "Corporate Social Responsibility (CSR) sebagai Implementasi Fikih Sosial untuk Pemberdayaan Masyarakat". Ahkam, Januari 2014: Volume XIV, Nomor 1, halaman. 53-62.
Sukmawaty, Siska. "Membangun Daerah Melalui Kebijakan Tanggung Jawab Sosial Perusahaan". Jurnal Selat, Mei 2017: Volume 4, Nomor 2, halaman. 205-218.

Sunaryo. "Corporate Social Responsibility (CSR) dalam Perspektif Pembangunan Berkelanjutan". Masalah-masalah Hukum, Januari 2015: Jilid 44, Nomor 1, halaman. 2633.

Utama, Andrew Shandy dan Rizana. "Implementasi Corporate Social Responsibility PT Riau Crumb Rubber Factory terhadap Masyarakat Kelurahan Sri Meranti Kota Pekanbaru".Novelty, Agustus 2017: Volume 8, Nomor 2, halaman.173-186.

\section{Peraturan Perundang-undangan:}

Undang-Undang Nomor 25 Tahun 2007 tentang Penanaman Modal.

Undang-Undang Nomor 40 Tahun 2007 tentang Perseroan Terbatas.

Peraturan Pemerintah Nomor 47 Tahun 2012 tentang Tanggung Jawab Sosial dan Lingkungan Perseroan Terbatas.

Peraturan Daerah Provinsi Riau Nomor 6 Tahun 2012 tentang Tanggung Jawab Sosial Perusahaan di Provinsi Riau. 